\title{
Effect of Telephonic Weight Loss Coaching Program on Body Composition among Health Field University
}

Students

\author{
Heba Abo Elazm Ibrahim ${ }^{1}$, Magda M. Mohsen², Afaf Abdelmalek \\ Hussein $^{3}$, Hanady Sh. Shehata ${ }^{4}$ \\ ${ }^{1}$ Clinical instructor of Family and Community Health Nursing, ${ }^{2}$ Professor of Family \\ and Community Health Nursing, ${ }^{3}$ Lecturer of Family and Community Health Nursing, \\ ${ }^{4}$ Assistant Professor of Family and Community Health Nursing, ${ }^{1234}$ Faculty of Nursing \\ - Menoufia University.
}

\begin{abstract}
Background: Mobile phone applications have been shown to successfully facilitate the self-management of obesity. Purpose: To examine the effect of telephonic weight loss coaching program on body composition among health field university students in Menoufia University. Design: A quasi-experimental with preposttest was utilized. Setting: This study was carried out in three health field faculties , Faculty of Nursing, Faculty of Veterinary Medicine and Faculty of Applied medical Science in Menoufia University, Menoufia Governorate. Sample: A multi-stage random sampling technique was utilized for selecting faculties and the academic year. A purposive sample of 200 university students was selected. Instruments: Three instruments were selected (social characteristics structured interviewing questionnaire, student health habits data, and Food frequency questionnaire, Bio physiological measurements: weight, height, BMI and body composition measurement and diet and exercise compliance assessment likert scale Results: The study findings revealed that after intervention program, there was statistically significant reduction in BMI and body fat percentage in the study group compared to control group. Conclusions: After implementation of telephonic weight loss coaching program on health field university students, there was statistically significant reduction in fat percentage and body mass index in study group compared to control group. Also there was statistically significant improvement in dietary and exercise health habits in study group compared to control group. Recommendations: The application of mobile health nursing intervention for the management of obesity should be encouraged. Offer weight loss app in Arabic version to be available to person with low or moderate educational level who cannot completely understand English language.
\end{abstract}

Key words: Obesity-Body Composition-Telephonic weight loss coaching - university students. 


\section{Introduction:}

Obesity is one of the most serious problems in the global public health domain. Obesity increases the risk of high blood pressure, dyslipidemia, type 2 diabetes, and cardiovascular diseases (WHO, 2018). Obesity and overweight are epidemic rising trends in both developed and developing countries. According to World Health Organization (WHO) estimates in 2016, there were approximately 1.9 billion overweight adults aged 18 and up, with at least 650 million being obese. The growing trend of people transitioning from overweight to obese occurs most frequently between the ages of 18 and 29 (Saghafi-Asl et al., 2021). Overweight and obesity are defined as abnormal or excessive fat accumulation that presents a risk to health. A body mass index (BMI) over 25 is considered overweight, and over 30 is obese (WHO, 2021).

College is a transitional period into adulthood during which students begin to make independent dietary and lifestyle choices and form potentially harmful habits. Such habits may persist into adulthood and have a negative impact on their long-term health and disease risk (Al-Awwad et al., 2021). A person's unhealthy eating habits and lack of physical activity are major contributors to becoming overweight or obese, which are linked to a lower quality of life and an increased risk of developing life-threatening diseases such as diabetes, cancer, and heart disease. It is critical to concentrate on changing everyday behaviors in order to lower chance of getting lifethreatening, potentially preventable disease (Parkman, 2020).

On college campuses today, a large number of students are seen carrying smart phones (such as the iPhone and Blackberry). Students use their mobile phones not only to make voice calls, but also to view course-related material, locate locations, check weather forecasts, obtain traffic updates, and connect to social networking applications such as Facebook, Twitter, and WhatsApp (Iqbal, 2017). The average daily usage of social applications is 2 hours and 27 minutes (Statista, 2021).

E-coaching is one form of technology being used for weight management. Ecoaching is a way that offers personal coaching, or support, in an electronic manner. E-coaches can offer supportive services through electronic mediums such as e-mail, the internet, or smart phone applications. This contact offers a suitable way to set goals, monitor daily diet and exercise programs, or to answer questions (Bisson, 2017). In many cases ecoaches are more available to clients and do not require an appointment in order to receive services, they are more available than health care workers, and can offer assistance immediately (Jefrey et al., 2019). This method provides direct communication when the assistance is needed, and might be an innovative step in fighting the obesity epidemic. Additionally, this form of support offers cost-effective, fast communication and satisfaction for busy people (Sullivan \& Lachman, 2016). Many people now prefer to use technology to facilitate their daily routine and to change the way people deal with weight management (Pal et al., 2018). Weight loss apps can provide an easy, safe and cheap way to overcome obesity by ensuring a high level of usability and encouraging individuals to change their lifestyle and become more active. Weight management applications encourage people with obesity to be active and change their lifestyle in order to overcome obesity (Nguyen, 2019). 
Field University Students

Community Health Nurses have a unique opportunity to contribute to the obesity epidemic. Nurses serve as role models for students and families by educating them on nutrition, the health-care system, and obesity-related illnesses, collaborate closely with students to provide health education on healthy diet and physical exercise, Nurses are also aware of the risks associated with obesity and can educate students on the more scientific aspects of this health issue. Students are better able to see the benefits of making healthier choices after learning how obesity can lead to diabetes, heart disease, and even cancer (Western Governs University, 2018).

A mobile health nursing intervention is defined as the use of electronic information and communication to support and promote health and wellbeing long-distance clinical healthcare, patient and health-related professional education (Department of Health and Human Services, 2018). Community health nurse can use mobile as an accessible communication method used for health nursing intervention. It has several uses as it helps access care services, improves the relationship between patients \& caregivers and implementing health education programs (Abujilban, 2019).Therefore the purpose of the present study was to examine the effect of telephonic weight loss coaching program on body composition among health field university students.

\section{Significance of the study:}

Obesity is a worldwide disease; according to world health organization more than 1.9 billion adults aged 18 years and older were overweight. Over 650 million adults of them were obese. In $2016,39 \%$ of adults aged 18 years and over $39 \%$ of men and $40 \%$ of women were overweight. Overall, about $13 \%$ of the world's adult population $(11 \%$ of men and $15 \%$ of women) was obese in 2016.The worldwide prevalence of obesity nearly tripled between 1975 and 2016 (WHO, 2020). In 2016, Kuwait had the highest prevalence of obesity among adults in the Middle East, at around 38 percent, and Yemen had the lowest, at around 17 percent. Adult obesity is prevalent in the Middle East and North Africa region, particularly in highincome countries such as the Gulf Cooperation Council (GCC) (Statista, 2020). Last survey of the Egyptian society in the framework of the " 100 Million Health" initiative revealed that about $25 \%$ of the population exhibited normal weight while the rest suffer from obesity and overweight (PuriMirza, 2019). The World Health Organization (WHO) ranks Egypt as the 18th most obese country in the world (Mehrzad, 2020).

Mobile health (mHealth) technologies are wireless devices and sensors (including mobile phones) that are designed to be carried and accessed during normal daily activities for the purposes of monitoring health status, changes in health outcomes, or wireless diagnosis and clinical decision support. Potential benefits of mHealth for obesity prevention and treatment include broad reach, real-time data collection, and the ability to deliver personalized, interactive, and adaptive interventions to subjects in their natural environment (Turner, 2016).

\section{Purpose:}

The purpose of the present study is to examine the effect of telephonic weight loss coaching program on body composition among health field university students.

\section{Research hypotheses}

1. Obese students who receive telephonic weight loss coaching program will probably have fewer fat percentage 
Field University Students

than students who do not receive such a program.

2. Obese students who receive telephonic weight loss coaching program will probably have fewer reduce body mass index than students who do not.

\section{Methods}

\section{Design:}

A quasi-experimental with pre and post-test design.

\section{Setting:}

This study was conducted at three health field faculties at Menoufia Governorate, Menoufia University, including Faculty of Nursing, Faculty of Veterinary Medicine and Faculty of Applied medical Science. These faculties were selected by using multistage random sample and purposively selected because they are a ParaMedical Faculties and known the language of the coaching program and able to understand the application.

\section{Sample:}

A multi-stage random sampling technique was used to select the setting through:

First stage: A purposive selection of 6 faculties out of 18 faculties at Menoufia Governorate, Menoufia University, including Faculty of Nursing, Faculty of Veterinary Medicine, Faculty of Applied medical Science, faculty of medicine, faculty of pharmacy and technical institute of nursing. These faculties were purposively selected because they know the language of the coaching program and are able to understand the application of the program.

Second stage : Three faculties were selected by simple random sample including Faculty of Nursing, Faculty of Veterinary Medicine, Faculty of Applied medical Science.
Third stage: One academic year was selected from each faculty by simple random sample (fourth year).

Fourth stage: Systematic random sample of 200 university students were selected.

Sample size and power of the study: The sample size was calculated for each group according to the following equation, and the results of the pilot study. Considering $\alpha$ type I error of $0.05, \beta$ type II error of 0.20 , a test power of $0.8, \mathrm{~m}=\mathrm{n} 1=$ size of sample from population 1 , and $\mathrm{d}=2$ as the least significant difference, $\mathrm{z} 1=$ standard normal deviate for two-tailed test based on alpha level (relates to the confidence interval level), $\mathrm{p}=$ percent of unexposed (control) with Outcome (body mass index) (Diggle et al., 2013).

\section{$N=2\left(\underline{\left.z_{1}-\alpha+z_{1}-\beta\right)^{2}} \sigma^{2}\{1+(m-1) p\}\right.$ md2}

\section{Inclusion criteria:}

- Body Mass Indexes (BMI) between 25 and $35 \mathrm{~kg} / \mathrm{m}^{2}$.

- Free from any medical problems that might influence body weight and

- Able to attend all scheduled sessions for them.

- No contraindication to physical exercises or handicap.

- No history of dietary regimen or regular exercise.

\section{Data collection instruments:}

Instrument one: Structured

\section{interviewing questionnaire:}

It was developed by researcher based on pertinent literature of Lupi et al., (2015). The questionnaire was translated from English to Arabic 
Field University Students

language. The Arabic version was modified by the researcher and reviewed by the supervisors to fit the target population. The questionnaire was divided into 3 parts:

a) Demographic characteristics of university students which include student name, age, gender, faculty name \& educational year.

b) Student health habits questionnaire which include dietary health habits (number of meals eaten every day, meal that not taken in day, meal taken outdoors, way of cooking food, fat used in cooking and health habits since starting studying in the university) \& physical exercise habits (type of exercise [walking, football, rang of motion], frequency of exercise \&duration of practicing exercise).

c) Food frequency questionnaire that include frequency of taking food (fruit, vegetables, cake, ice cream, chocolate, biscuits, rice, pasta, meat, chicken, fish, dairy products, processed meat, egg, chips, bread, cereals, pizza, ready canned food, fruit juice, tea, coffee, milk, soft fizzy drinks, sauces and snacks) per week or per month.

Instrument two Bio-physiological Measurement which include two

parts:

a) Body Mass Index (BMI): Body Weight and Height; is weight in kilograms divided by the squared height in meters.

b) Body Composition. Body fat percentage and lean body mass was measured with a total in body weight scale at baseline, 2 months, and 4 months. Total in body weight scale has been shown to be a valid and reliable instrument for measuring body fat percentage and water percentage mass. This measure was collected at the pretest, posttest after two months and posttest after four months.

Instrument three: The compliance assessment likert scale:

It was adapted from Dermirtas \& Akbayrak, (2017) who used this scale for assessing diabetic patient compliance to dietary instructions, evaluate the students' response and compliance toward the individualized telephone weight loss coaching program for weight control It includes items that are measured by three points likert scale ( always, sometimes \& never). It includes two parts diet compliance that include the students' degree of adherence to the prescribed diet regimen for weight reduction;( complete, partial or no compliance at all) and exercises'. Compliance includes the students' degree of adherence, (complete, partial or no compliance at all) regarding the prescribed exercises regimen for weight reduction.

\section{Validity of Instruments:}

Three community health nursing experts used content validity to evaluate the questionnaire's validity. The Experts examined the relevancy, clarity, fluency, and simplicity of each component in the questionnaire and concluded that it is useful and helpful.

\section{Reliability of instruments:}

Reliability of the three instruments was estimated among 10 university students by using test-retest method with two weeks apart between them. Then Cronbach alpha reliability test was done through SPSS computer package. It was 0.85 for "Structured interviewing questionnaire" with its two parts A. Demographic characteristics of student, and B. "Student health habits including practicing exercise, type of exercise 
Field University Students

(waling, football, rang of motion) and frequency of exercise). Also, Cronbach alpha reliability test that was used for instrument two (Biophysiological Measurements) was 0.81. Regarding instrument three: The compliance assessment Likert scale (Dermirtas \& Akbayrak, 2017), it had 0.88 Cronbach alpha reliability test That three instruments were reliable to achieve the objectives of the study.

\section{Procedure}

- An official letter was addressed about the purpose of the study from the faculty of nursing, Menoufia University to the dean of each selected faculty, requesting their cooperation and permission to conduct the study.

- Formal letter was forewarded from the Dean Faculty of Nursing, Menoufia University and directed to the Deans of the selected faculties containing the purpose and methods and asking their permission for data collection.

- Once an official permission was granted and informed consent to proceed with the study, the researchers started data collection from university students who fulfilled the selection criteria. Data collection was conducted two days per week for four months through using self-administered structured questionnaire which included demographic characteristics, Health habits questionnaire (diet-physical exercise), Questionnaire for food frequency, Bio physiologic measurement, student's compliance with weight loss program programme.

- Before distributing the questionnaire, the researcher introduced herself to the students. Then brief description of the purpose of the study and type of questionnaire were explained to the students to gain their cooperation to share in the study. Questionnaires were distributed to the selected participants who agree to participate in the study.

- Study sample was divided into two groups (study group and control group). Each group was divided into3 groups. Each group consists of 30-35 student (nursing faculty group, applied medical science faculty group and veterinary medicine faculty group). Each group (study group and control group) was interviewed in lecture room to ensure the accessibility of students. The average time taken for completing questionnaires was around 20-30 minutes.

- Base-line data about complete bio physiological measurements was taken (pre - test).

- Bio physiological measurement which included weight that was measured on a digital electronic scale. Students weight was measured in kilograms (kg) using a weight scale after asking them to evacuate their bladder. It was checked weekly with known calibration weights. Weight measures was taken while the student wearing little or no outer clothing and no shoes. The weight was approximated to nearest $0.1 \mathrm{~kg}$ (Shehata, 2015), Height that was measured; approximated to nearest $0.1 \mathrm{~cm}$ on a Holtain portable anthropometric (Shehata, 2015) and body mass index (BMI) by dividing weight in kilograms by squared height in meters.

- Body composition measurements which include Fat percentage and water percentage were measured using body measurement scale by having the student stand on the scale and taking the percentage of fat and 
Field University Students

percentage of water written on the digital screen of the scale After that students were provided group instructions about how to use telephonic weight loss program application and make setup on their phones [Weight loss coaching program is a diet application only for losing weight not for gaining weight.it is powered by artificial intelligence, it granted weight loss in 35 days or less (up to5 $\mathrm{kg}$ or 12 pounds), it give motivational daily tips to help you get rid of obesity, it built in weight tracker to track progress, it offers shopping list every week, track weight loss progress in graphs, supports both kilogram \& pounds, it give diet program for five weeks according to every subject BMI .Every day covers 3 main meals and snacks, it give also daily video exercise for 15 minutes. Diet and exercise are changed after 5 weeks according to change in subject body weight]

- Telephone number of each student was taken to create two what's app groups (one for study group and one for control group) Students in the study group received explanation about weight loss coaching program and were reminded about time of post assessment, Students in the control group did not receive health education coaching sessions and were only reminded with the time of post assessment.

- After implementation of the telephonic weight loss coaching program, bio physiological measurements, student health habits, food frequency questionnaire and compliance to telephonic weight loss coaching program were re-measured after 2 months and 4 months from the start of the telephonic weight loss coaching for study sample (study \&control group).

- After completion of the study telephonic weight loss coaching was explained to control group.

- Study period: Data collection for this study was extended for the period starting from January 2021 to the end of April 2021.

\section{Statistical Analysis}

Data was entered and analyzed by using SPSS (Statistical Package for Social Science) statistical package version 22. Graphics were done using Excel program. Quantitative data were presented by mean $(\mathrm{X})$ and standard deviation (SD). It was analyzed using student $t$ test for comparison between two means, and ANOVA (F) test was used for comparison between more than two means. Qualitative data were presented in the form of frequency distribution tables, number and percentage. It was analyzed by chisquare $\left(\chi^{2}\right)$ test. However, if an expected value of any cell in the table was less than 5, Fisher Exact test was used (if the table was 4 cells), or Likelihood Ratio (LR) test (if the table was more than 4 cells). Level of significance was set as $\mathrm{P}$ value $<0.05$ for all significant tests. In this study, repeated Friedman Test (type of Chi square test for repeated procedures for qualitative data) for comparison of diet health habits, exercise health habits, and compliance assessment between the three time points of intervention in cases group.

\section{Results:}

Table 1: shows that all control group $(100 \%)$ was 22 years old, but $12 \%$ of study group were aged 21 Years old. Majority of studied university students were females $(86 \%$ for control and $71 \%$ for study groups respectively. Regarding father's education, more 
Field University Students

than half of both study and control group had university education $(52 \%$ $54 \%$ ) respectively. Also, the majority of both control and study group had families with enough income per month (45\% for control, and $50 \%$ for study respectively).

Table 2: shows that a highly statistical significant improvement was found between Posttest 1 and posttest2 ( $p<0.0001$ regarding diet health habits among study group. Also, mean number of intake of meals increased from $2.7 \pm 0.5$ for pre intervention to $2.95 \pm 0.2$ for post 1 intervention and the difference was highly statistically significant $\quad(\mathrm{P} 2<0.0001) . \quad$ For comparison between mean number of meals pre intervention with that of posttest 2 following intervention and the difference was highly statistically significant ( $P$ 3<0.0001). Regarding meals eaten outdoor, the majority of study group were eating meals out door $(81 \%)$ on pre intervention, which was decreased to $27 \%$ in posttest 1 and posttest 2 following intervention and the difference was statistically significant $(\mathrm{P} 4<0.001)$.

Table 3: Represented that there was a highly statistical significant improvement $(p<0.0001)$ in study group' exercise health habits during posttest 1 and posttest 2 following the intervention program. In posttest 1 exercise health habits were $85 \%$ compared with $19 \%$ pre intervention and remained the same in post $2(85 \%)$, however, among control group, the exercise health habits trend was different. For the control group, no statistical significant difference was found between pre intervention, posttest 1 and 2 .

Table 4: shows that there was highly statistically significant difference in body fat (\%) among study group in pre intervention, posttest 1 and posttest 2 as body fat $(\%)$ decreased from $37.8 \pm 1.8$ $\%$ to $29.8 \pm 3.1$, and to $24.8 \pm 8.2$ respectively. However, among control group, the difference was not significant statistically as there was a slight decrease in pre intervention, posttest1and posttest 2 as body fat (\%) decreased from $38.0 \pm 1.0 \%$ to $37.9 \pm 0.9 \%$ and to $37.9 \pm 0.9 \%$ respectively.

Table 5: shows that there was a highly statistically significant improvement $(\mathrm{p}<0.0001)$ in BMI among study groupon posttest1 and posttest2 following intervention of the program. The posttest 1 mean \pm SD of BMI was reduced from $29.4 \pm 3.5$ on pre intervention to $28.4 \pm 1.4 \%$ in posttest 1 intervention, and $25.9 \pm 2.2$ in posttest2., and the difference was highly statistically significant $(\mathrm{F}=181.9, \mathrm{P}<0.0001)$. However, among control group, the BMI trend was different. The posttests 1 and 2' means \pm SD of BMI were nearly similar $29.8 \pm 1.7$ in posttest 1 and $29.8 \pm 1$.7in posttest2. When you write English try to start with the subject then write the verb followed by the adverb in order to facilitate reading for the others.

\section{RESULTS}


Effect of Telephonic Weight Loss Coaching Program on Body Composition among Health

Field University Students

Table (1): Distribution of socio demographic characteristics among University students

\begin{tabular}{|c|c|c|c|c|c|c|c|}
\hline \multirow{2}{*}{\multicolumn{2}{|c|}{ Demographic characteristics }} & \multicolumn{4}{|c|}{ Groups } & \multicolumn{2}{|c|}{ Total } \\
\hline & & \multicolumn{2}{|c|}{ Study } & \multicolumn{2}{|c|}{ Control } & \multirow[b]{2}{*}{ No. } & \multirow[b]{2}{*}{$\%$} \\
\hline & & No. & $\%$ & No. & $\%$ & & \\
\hline \multirow[t]{2}{*}{ Age } & 21 years & 12 & 12 & 0 & 0 & 12 & 6 \\
\hline & 22 Years & 88 & 88 & 100 & 100 & 188 & 94 \\
\hline \multirow[t]{2}{*}{ Gender } & Male & 29 & 29 & 14 & 14 & 43 & 21.5 \\
\hline & Female & 71 & 71 & 86 & 86 & 157 & 78.5 \\
\hline Marital status & Single & 100 & 100 & 100 & 100 & 200 & 100 \\
\hline \multirow{4}{*}{ Father education } & cannot Read \& Write & 3 & 3 & 13 & 13 & 16 & 8 \\
\hline & Basic education. & 40 & 40 & 13 & 13 & 53 & 26.5 \\
\hline & Secondary education & 5 & 5 & 20 & 20 & 25 & 12.5 \\
\hline & University education. & 52 & 52 & 54 & 54 & 106 & 53 \\
\hline \multirow{3}{*}{$\begin{array}{l}\text { Father } \\
\text { occupation }\end{array}$} & Employee & 60 & 60 & 61 & 61 & 121 & 60.5 \\
\hline & Workers & 23 & 23 & 25 & 25 & 48 & 24 \\
\hline & Free work & 17 & 17 & 14 & 14 & 31 & 15.5 \\
\hline \multirow{5}{*}{$\begin{array}{l}\text { Mother } \\
\text { education }\end{array}$} & cannot Read\& Write & 21 & 21 & 14 & 14 & 35 & 17.5 \\
\hline & Read \& Write & 3 & 3 & 13 & 13 & 16 & 8 \\
\hline & Basic education. & 18 & 18 & 13 & 13 & 31 & 15.5 \\
\hline & Secondary education & 14 & 14 & 13 & 13 & 27 & 13.5 \\
\hline & University education. & 44 & 44 & 47 & 47 & 91 & 45.5 \\
\hline \multirow{2}{*}{$\begin{array}{l}\text { Mother } \\
\text { occupation }\end{array}$} & Employee & 38 & 38 & 34 & 34 & 72 & 36 \\
\hline & Housewife & 62 & 62 & 66 & 66 & 128 & 64 \\
\hline \multirow{3}{*}{ Income } & Not enough & 15 & 15 & 14 & 14 & 29 & 14.5 \\
\hline & Enough & 50 & 50 & 45 & 45 & 95 & 47.5 \\
\hline & Enough \& save & 35 & 35 & 41 & 41 & 76 & 38 \\
\hline Total & & 100 & 100 & 100 & 100 & 200 & 100 \\
\hline
\end{tabular}

Table 2: Diet health habits among study and control group during the study period (pre, post1, and post 2 intervention $)(\mathrm{N}=200)$ 
Effect of Telephonic Weight Loss Coaching Program on Body Composition among Health Field University Students

\begin{tabular}{|c|c|c|c|c|c|c|c|c|c|c|c|c|c|c|c|c|c|}
\hline \multirow[t]{3}{*}{ Diet health habits } & \multicolumn{5}{|c|}{ Before Intervention } & \multicolumn{5}{|c|}{ Post1 after intervention } & \multicolumn{5}{|c|}{ Post2 after intervention } & \multirow{2}{*}{\multicolumn{2}{|c|}{ *Friedman $\chi^{2}$ test, }} \\
\hline & \multicolumn{2}{|c|}{ Study group } & \multicolumn{2}{|c|}{ Control } & \multirow{2}{*}{$\mathbf{P 1}$} & \multicolumn{2}{|c|}{ Study group } & \multicolumn{2}{|c|}{ Control } & \multirow[b]{2}{*}{$\mathbf{P 2}$} & \multicolumn{2}{|c|}{ Study group } & \multicolumn{2}{|c|}{ Control } & \multirow[b]{2}{*}{ P3 } & & \\
\hline & No. & $\%$ & No. & $\%$ & & No. & $\%$ & No. & $\%$ & & No. & $\%$ & No. & $\%$ & & $\begin{array}{c}\text { Study } \\
\text { P4 }\end{array}$ & $\begin{array}{c}\text { Contro } \\
\text { P5 }\end{array}$ \\
\hline $\begin{array}{l}\text { Meals per day: } \\
\text { Mean } \pm \text { SD }\end{array}$ & \multicolumn{2}{|c|}{$2.7 \pm 0.5$} & \multicolumn{2}{|c|}{$2.8 \pm 0.4$} & $\begin{array}{c}\mathrm{t}=1.6, \mathrm{P}=0.0 \\
7\end{array}$ & \multicolumn{2}{|c|}{$2.95 \pm 0.2$} & \multicolumn{2}{|c|}{$2.7 \pm 0.4$} & $\begin{array}{c}\mathrm{t}=5.5, \mathrm{P}<0.00 \\
01\end{array}$ & \multicolumn{2}{|c|}{$2.96 \pm 0.19$} & \multicolumn{2}{|c|}{$2.7 \pm 0.4$} & $\begin{array}{l}\mathrm{t}=4.6, \mathrm{P}<0.0 \\
001\end{array}$ & $<0.001$ & $=0.94$ \\
\hline $\begin{array}{l}\text { Meal you do not eat: Break } \\
\text { fast } \\
\text { Lunch } \\
\text { Dinner }\end{array}$ & $\begin{array}{c}89 \\
1 \\
10\end{array}$ & $\begin{array}{c}89 \\
1 \\
10\end{array}$ & $\begin{array}{c}79 \\
7 \\
14\end{array}$ & $\begin{array}{c}79 \\
7 \\
14\end{array}$ & $\begin{array}{c}\mathrm{LR}=6.3, \mathrm{P}=0 \\
.04\end{array}$ & $\begin{array}{c}26 \\
2 \\
72\end{array}$ & $\begin{array}{c}26 \\
2 \\
72\end{array}$ & $\begin{array}{l}66 \\
12 \\
22\end{array}$ & $\begin{array}{l}66 \\
12 \\
22\end{array}$ & $\begin{array}{l}X^{2}=51.1 \\
P<0.0001\end{array}$ & $\begin{array}{c}20 \\
4 \\
76\end{array}$ & $\begin{array}{c}20 \\
4 \\
76\end{array}$ & $\begin{array}{l}59 \\
27 \\
14\end{array}$ & $\begin{array}{l}59 \\
27 \\
14\end{array}$ & $\begin{array}{c}\mathrm{X}^{2}=79.0, \mathrm{P}<0 \\
0001\end{array}$ & $<0.0001$ & $=0.09$ \\
\hline $\begin{array}{l}\text { Meals outdoors: } \\
\text { Yes } \\
\text { No }\end{array}$ & $\begin{array}{l}81 \\
19\end{array}$ & $\begin{array}{l}81 \\
19\end{array}$ & $\begin{array}{c}100 \\
0\end{array}$ & $\begin{array}{c}100 \\
0\end{array}$ & $\begin{array}{c}X^{2}=18.7, P<0 \\
.0001\end{array}$ & $\begin{array}{l}27 \\
73\end{array}$ & $\begin{array}{l}27 \\
73\end{array}$ & $\begin{array}{c}100 \\
0\end{array}$ & $\begin{array}{c}100 \\
0\end{array}$ & $\begin{array}{r}X^{2}=114, \\
P<0.0001\end{array}$ & $\begin{array}{l}27 \\
73\end{array}$ & $\begin{array}{l}27 \\
73\end{array}$ & $\begin{array}{c}100 \\
0\end{array}$ & $\begin{array}{c}100 \\
0\end{array}$ & $\begin{array}{l}X^{2}=114, \\
P<0.0001\end{array}$ & $<0.0001$ & ---- NA \\
\hline If yes, which meal: & & & & & & & & & & & & & & & & & \\
\hline $\begin{array}{l}\text { Break fast } \\
\text { Lunch }\end{array}$ & $\begin{array}{l}20 \\
61\end{array}$ & $\begin{array}{l}24.7 \\
75.3\end{array}$ & $\begin{array}{l}79 \\
21\end{array}$ & $\begin{array}{l}79 \\
21\end{array}$ & $\begin{array}{c}x=53.5, \mathrm{P}<0 \\
.0001\end{array}$ & $\begin{array}{l}17 \\
10\end{array}$ & $\begin{array}{l}63 \\
37\end{array}$ & $\begin{array}{l}88 \\
12\end{array}$ & $\begin{array}{l}88 \\
12\end{array}$ & $\begin{array}{c}\mathrm{X}^{2}=9.6, \mathrm{P}<0.00 \\
2\end{array}$ & $\begin{array}{l}17 \\
10\end{array}$ & $\begin{array}{l}63 \\
37\end{array}$ & $\begin{array}{l}86 \\
14\end{array}$ & \begin{tabular}{|l|}
86 \\
14
\end{tabular} & $\begin{array}{l}\mathrm{X}^{2}=6.8 \mathrm{P}<0 \\
09\end{array}$ & $<0.0001$ & 0.18 \\
\hline $\begin{array}{l}\text { Method of cooking food } \\
\text { Parboiled } \\
\text { Foundry } \\
\text { Raw }\end{array}$ & $\begin{array}{c}0 \\
100 \\
0\end{array}$ & $\begin{array}{c}0 \\
100 \\
0\end{array}$ & $\begin{array}{c}0 \\
100 \\
0\end{array}$ & $\begin{array}{c}0 \\
100 \\
0\end{array}$ & ------NA & $\begin{array}{c}7 \\
25 \\
68\end{array}$ & $\begin{array}{c}7 \\
25 \\
68\end{array}$ & $\begin{array}{c}0 \\
100 \\
0\end{array}$ & $\begin{array}{c}0 \\
100 \\
0\end{array}$ & $\begin{array}{c}\mathrm{LR}=152.2, \mathrm{P}<0 \\
0001\end{array}$ & $\begin{array}{l}16 \\
25 \\
59\end{array}$ & $\begin{array}{l}16 \\
25 \\
59\end{array}$ & $\begin{array}{c}0 \\
100 \\
0\end{array}$ & $\begin{array}{c}0 \\
100 \\
0\end{array}$ & $\begin{array}{c}\mathrm{X}^{2}=120, \mathrm{P}<0.0 \\
001\end{array}$ & $<0.0001$ & ----NA \\
\hline Fat used in cooking & & & & & & & & & & & & & & & & & \\
\hline $\begin{array}{l}\text { Vegetable oil } \\
\text { Industry margarine } \\
\text { mixed fat }\end{array}$ & \begin{tabular}{c|}
0 \\
24 \\
76
\end{tabular} & \begin{tabular}{|l|}
0 \\
24 \\
76
\end{tabular} & $\begin{array}{c}0 \\
0 \\
100\end{array}$ & $\begin{array}{c}0 \\
0 \\
100\end{array}$ & $\begin{array}{l}\mathrm{X}^{2}=27.3, \mathrm{P}< \\
0.0001\end{array}$ & $\begin{array}{l}79 \\
21 \\
0\end{array}$ & \begin{tabular}{|l|}
79 \\
21 \\
0
\end{tabular} & $\begin{array}{l}0 \\
0 \\
100\end{array}$ & $\begin{array}{l}0 \\
0 \\
100\end{array}$ & $\begin{array}{c}X=130.0 \\
P<0.001\end{array}$ & $\begin{array}{c}67 \\
9 \\
24\end{array}$ & $\begin{array}{c}67 \\
9 \\
24\end{array}$ & $\begin{array}{c}0 \\
0 \\
100\end{array}$ & $\begin{array}{c}0 \\
0 \\
100\end{array}$ & $\begin{array}{c}\mathrm{LR}=155.4, \mathrm{P}< \\
0.0001\end{array}$ & $<0.0001$ & -----NA \\
\hline $\begin{array}{l}\text { Health habits changed after } \\
\text { Yes } \\
\text { No }\end{array}$ & $\begin{array}{c}96 \\
4\end{array}$ & $\begin{array}{c}96 \\
4\end{array}$ & $\begin{array}{c}100 \\
0\end{array}$ & $\begin{array}{c}100 \\
0\end{array}$ & $\begin{array}{c}\text { Fisher }=0.12 \\
\text { NS }\end{array}$ & $\begin{array}{c}96 \\
4\end{array}$ & $\begin{array}{c}96 \\
4\end{array}$ & $\begin{array}{c}100 \\
0\end{array}$ & $\begin{array}{c}100 \\
0\end{array}$ & $\begin{array}{l}\mathrm{LR}=5.6, \\
\mathrm{p}<0.02\end{array}$ & $\begin{array}{c}96 \\
4\end{array}$ & $\begin{array}{c}96 \\
4\end{array}$ & $\begin{array}{c}100 \\
0\end{array}$ & $\begin{array}{c}100 \\
0\end{array}$ & $\begin{array}{c}\mathrm{LR}=5.6, \mathrm{p}<0.0 \\
2\end{array}$ & ---NA & ----NA \\
\hline $\begin{array}{l}\text { Causes of change : Most } \\
\text { time out home } \\
\text { Eating fast food with friends }\end{array}$ & 47 & $\begin{array}{l}49 \\
51\end{array}$ & 34 & 34 & $\mathrm{X}^{2}=4.5, \mathrm{P}<0$. & 42 & $\begin{array}{l}43.8 \\
56.2\end{array}$ & 48 & 48 & $\begin{array}{c}\mathrm{K}^{2}=0.35, \mathrm{P}=0.55 \\
\mathrm{NS}\end{array}$ & 44 & 45.8 & 46 & 46 & $\begin{array}{l}\mathrm{X}^{2}=0.001 \\
\mathrm{P}=0.98\end{array}$ & 0.04 & 0.06 \\
\hline $\begin{array}{l}\text { Eating fast food with friends } \\
\text { Staying in university city }\end{array}$ & $\begin{array}{c}49 \\
0\end{array}$ & $\begin{array}{c}51 \\
0\end{array}$ & $\begin{array}{c}66 \\
0\end{array}$ & $\begin{array}{c}66 \\
0\end{array}$ & 03 & 54 & $\begin{array}{c}56.2 \\
0\end{array}$ & $\begin{array}{c}52 \\
0\end{array}$ & $\begin{array}{c}52 \\
0\end{array}$ & & 52 & $\begin{array}{c}54.2 \\
0\end{array}$ & $\begin{array}{c}54 \\
0\end{array}$ & $\begin{array}{c}54 \\
0\end{array}$ & NS & & \\
\hline
\end{tabular}




\section{Effect of Telephonic Weight Loss Coaching Program on Body Composition among Health Field University Students}

$\mathrm{P} 1=$ Comparison of each component of diet health habit pre intervention between study and control groups.

P2= Comparison of each component of diet health habit post 1 intervention between study and control groups.

P3= Comparison of each component of diet health habit post2 intervention between study and control groups.

P4= Comparison between study in pre , post 1 intervention and post 2 intervention by using Repeated Friedman Test.

P5= Comparison between control in pre , post 1 intervention and post2 intervention by using Repeated Friedman Test.

$*^{2} \quad$ : Using Repeated Friedman Test ( type of Chi square test for repeated procedures for qualitative data) for comparison of (diet health habits) between the three time points of intervention in study group (P4). However, in control group (P5), this test was NA (Not applicable) in four items of diet health habits as no statistics are computed because diet health habits in pre, post 1 and post 2 intervention is a constant.

Table 3: Exercise health habits among study and control group during the study period (pre, post1, and post2 intervention) ( $\mathrm{N}=200)$

\begin{tabular}{|c|c|c|c|c|c|c|c|c|c|c|c|c|c|c|c|c|c|}
\hline \multirow{3}{*}{ Exercise health habits } & \multicolumn{5}{|c|}{ Before Intervention } & \multicolumn{5}{|c|}{ Post1 after intervention } & \multicolumn{5}{|c|}{ Post2 after intervention } & \multirow{2}{*}{\multicolumn{2}{|c|}{$* \chi^{2}$}} \\
\hline & \multicolumn{2}{|c|}{ Study group } & \multicolumn{2}{|c|}{ Control } & \multirow[b]{2}{*}{ P1 } & \multicolumn{2}{|c|}{ Study group } & \multicolumn{2}{|c|}{ Control } & \multirow[b]{2}{*}{$\mathbf{P 2}$} & \multicolumn{2}{|c|}{ Study group } & \multicolumn{2}{|c|}{ Control } & \multirow[b]{2}{*}{$\mathbf{P 3}$} & & \\
\hline & No. & $\%$ & No. & $\%$ & & No. & $\%$ & No. & $\%$ & & No. & $\%$ & No. & $\%$ & & Study P4 & $\begin{array}{c}\text { Control } \\
\text { P5 }\end{array}$ \\
\hline $\begin{array}{l}\text { do you practice exercise? } \\
\text { Yes } \\
\text { No }\end{array}$ & $\begin{array}{l}19 \\
81\end{array}$ & $\begin{array}{l}19 \\
81\end{array}$ & $\begin{array}{l}17 \\
83\end{array}$ & $\begin{array}{l}17 \\
83\end{array}$ & $\begin{array}{c}X^{2}=0.13 \\
P=0.71\end{array}$ & $\begin{array}{l}85 \\
15\end{array}$ & $\begin{array}{l}85 \\
15\end{array}$ & $\begin{array}{l}11 \\
89\end{array}$ & $\begin{array}{l}11 \\
89\end{array}$ & $\begin{array}{l}X^{2}=109.2 \\
P<0.0001\end{array}$ & $\begin{array}{l}85 \\
15\end{array}$ & $\begin{array}{l}85 \\
15\end{array}$ & $\begin{array}{c}9 \\
91\end{array}$ & $\begin{array}{c}9 \\
91\end{array}$ & $\begin{array}{l}X^{2}=115.4 \\
P<0.0001\end{array}$ & $<0.001$ & $\begin{array}{c}3.3, \\
\mathrm{P}=0.06\end{array}$ \\
\hline $\begin{array}{l}\text { If yes: exercise type: } \\
\text { Walking } \\
\text { Football } \\
\text { Walk to gardens }\end{array}$ & $\begin{array}{c}6 \\
10 \\
3\end{array}$ & $\begin{array}{l}31.6 \\
52.6 \\
15.8\end{array}$ & $\begin{array}{l}7 \\
8 \\
2\end{array}$ & $\begin{array}{c}41.2 \\
47 \\
11.8\end{array}$ & $\begin{array}{c}\mathrm{LR}=0.39 \\
\mathrm{P}=0.82 \mathrm{NS}\end{array}$ & $\begin{array}{l}68 \\
17 \\
0\end{array}$ & $\begin{array}{c}80 \\
20 \\
0\end{array}$ & $\begin{array}{l}6 \\
5 \\
0\end{array}$ & $\begin{array}{c}54.5 \\
45.5 \\
0\end{array}$ & $\begin{array}{l}X^{2}=37.9, \\
P<0.0001\end{array}$ & $\begin{array}{c}61 \\
24 \\
0\end{array}$ & $\begin{array}{c}71.8 \\
28.2 \\
0\end{array}$ & $\begin{array}{l}3 \\
6 \\
0\end{array}$ & $\begin{array}{c}33.3 \\
66.7 \\
0\end{array}$ & $\begin{array}{c}\mathrm{K}^{2}=25.3, \mathrm{P}<0 \\
0001\end{array}$ & $<0.0001$ & $\begin{array}{l}0.53 \\
0.46\end{array}$ \\
\hline $\begin{array}{l}\text { Duration of exercise /day?: } \\
15:<30 \mathrm{~min} \text { a day } \\
\text { 30: } 60 \mathrm{~min} \text { a day } \\
>60 \mathrm{~min} \text { a day }\end{array}$ & $\begin{array}{l}5 \\
9 \\
5\end{array}$ & $\begin{array}{l}26.347 \\
.426 .3\end{array}$ & $\begin{array}{c}3 \\
10 \\
4\end{array}$ & $\begin{array}{l}17.7 \\
58.8 \\
23.5\end{array}$ & $\begin{array}{l}\mathrm{LR}=0.55, \mathrm{p} \\
=0.75 \mathrm{NS}\end{array}$ & $\begin{array}{c}35 \\
50 \\
0\end{array}$ & $\begin{array}{c}41.2 \\
8.8 \\
0\end{array}$ & $\begin{array}{l}4 \\
7 \\
0\end{array}$ & $\begin{array}{c}36.4 \\
63.6 \\
0\end{array}$ & $\begin{array}{c}X^{2}=90.1 \\
P<0.0001\end{array}$ & $\begin{array}{c}23 \\
62 \\
0\end{array}$ & $\begin{array}{c}27.1 \\
72.9 \\
0\end{array}$ & $\begin{array}{l}7 \\
2 \\
0\end{array}$ & $\begin{array}{c}77.8 \\
22.2 \\
0\end{array}$ & $\begin{array}{l}X^{2}=95.3 \\
P<0.0001\end{array}$ & $<0.0001$ & $\begin{array}{l}2.4 \\
P=0.15\end{array}$ \\
\hline $\begin{array}{l}\text { Frequency of exercise?: } \\
\text { Every day } \\
4-6 \text { time / week } \\
1-3 \text { times / week }\end{array}$ & $\begin{array}{l}5 \\
9 \\
5\end{array}$ & $\begin{array}{l}26.3 \\
47.4 \\
26.3\end{array}$ & $\begin{array}{l}7 \\
4 \\
6\end{array}$ & $\begin{array}{l}41.2 \\
23.5 \\
35.3\end{array}$ & $\begin{array}{c}\mathrm{X}^{2}=2.2, \\
\mathrm{P}=0.32 \mathrm{NS}\end{array}$ & $\begin{array}{l}32 \\
32 \\
21\end{array}$ & $\begin{array}{l}37.6 \\
37.6 \\
24.8\end{array}$ & $\begin{array}{l}5 \\
4 \\
2\end{array}$ & $\begin{array}{l}45.5 \\
36.4 \\
18.1\end{array}$ & $\begin{array}{c}\mathrm{X}^{2}=6.3, \mathrm{P}<0.0 \\
2\end{array}$ & $\begin{array}{c}56 \\
8 \\
21\end{array}$ & $\begin{array}{c}65.9 \\
9.4 \\
24.7\end{array}$ & $\begin{array}{l}6 \\
2 \\
1\end{array}$ & $\begin{array}{l}66.7 \\
22.2 \\
11.1\end{array}$ & $\begin{array}{c}\mathrm{X}^{2}=6.8, \mathrm{P}<0 \\
04\end{array}$ & $<0.0001$ & $\begin{array}{c}0.18 \\
\mathrm{P}=0.67\end{array}$ \\
\hline Total & 19 & 100 & 17 & 100 & & 85 & 100 & 11 & 100 & & 85 & 100 & 9 & 100 & & & \\
\hline
\end{tabular}


Effect of Telephonic Weight Loss Coaching Program on Body Composition among Health Field

\section{University Students}

$\mathrm{P} 1=$ Comparison of mean and SD of each question of practice exercise before intervention in the study and control groups.

P2 = Comparison of mean and SD of each question of practice exercise post 1 intervention in the study and control groups.

$\mathrm{P} 3=$ Comparison of mean and SD of each question of practice exercise post 2 intervention in the study and control groups.

$* \chi^{2} \quad$ : Using Repeated Friedman Test (type of Chi square test for repeated procedures for qualitative data) for comparison of (exercise health habits) between the three time points of intervention in study group. However, in control group, this test was NA (Not applicable) in all items of exercise health habits as no statistics are computed because exercise health habits in pre, post 1 and post 2 intervention is a constant .

Table 4: Effect of TWLCP on Body composition among study and control university students in pre, post1, and post 2 intervention $(\mathrm{N}=200)$

\begin{tabular}{|c|c|c|c|c|c|c|c|c|}
\hline \multirow{2}{*}{$\begin{array}{c}\text { Body } \\
\text { composition }\end{array}$} & \multicolumn{2}{|c|}{ Pre intervention } & \multicolumn{2}{|c|}{ Post 1 intervention } & \multicolumn{2}{|c|}{ Post 2 intervention } & \multirow{2}{*}{\begin{tabular}{|l|} 
F test/P4 \\
Study
\end{tabular}} & \multirow{2}{*}{$\begin{array}{l}\text { F test/P5 } \\
\text { Control }\end{array}$} \\
\hline & $\begin{array}{c}\text { Study } \\
\text { Mean } \pm \text { SD }\end{array}$ & $\begin{array}{l}\text { Control } \\
\text { Mean } \pm \text { SD }\end{array}$ & $\begin{array}{r}\text { Study } \\
\text { Mean } \pm \text { SD }\end{array}$ & $\begin{array}{c}\text { Control } \\
\text { Mean } \pm \text { SD }\end{array}$ & $\begin{array}{c}\text { Study } \\
\text { Mean } \pm \text { SD }\end{array}$ & $\begin{array}{c}\text { Control } \\
\text { Mean } \pm \text { SD }\end{array}$ & & \\
\hline Fat \% & $37.8 \pm 1.8$ & $38.0 \pm 1.0$ & $29.8 \pm 3.1$ & $37.9 \pm 0.9$ & $24.8 \pm 8.2$ & $37.9 \pm 0.9$ & $\begin{array}{c}\mathrm{F}=54.7, \\
\mathrm{P}<0.0001\end{array}$ & $\begin{array}{c}\mathrm{F}=1.02, \mathrm{P}= \\
0.14\end{array}$ \\
\hline $\mathbf{P}_{\text {value }}$ & \multicolumn{2}{|c|}{$\mathrm{t}=1.15, \mathrm{P} 1=0.11$} & & & \multicolumn{2}{|c|}{$\mathrm{t}=7.2, \mathrm{P}<0.0001$} & & \\
\hline Body water & $47.8 \pm 1.6$ & $48.9 \pm 1.3$ & $49.2 \pm 4.5$ & $48.9 \pm 1.3$ & $49.5 \pm 4.5$ & $48.9 \pm 1.3$ & $\begin{array}{l}F=1.19, \\
P=0.11\end{array}$ & $\begin{array}{l}\mathrm{F}=0.472, \mathrm{P} \\
=0.21\end{array}$ \\
\hline $\mathbf{P}_{\text {value }}$ & $\mathbf{t}=1.17$ & $=0.24$ & $\mathbf{t}=0.61$ & $\mathrm{P} 1=0.54$ & $t=1$ & $P=0.24$ & & \\
\hline
\end{tabular}

Table 5: Effect of TWLCP on Anthropometric measures among study and control in pre, post1, and post2 intervention $(\mathbf{N}=\mathbf{2 0 0})$

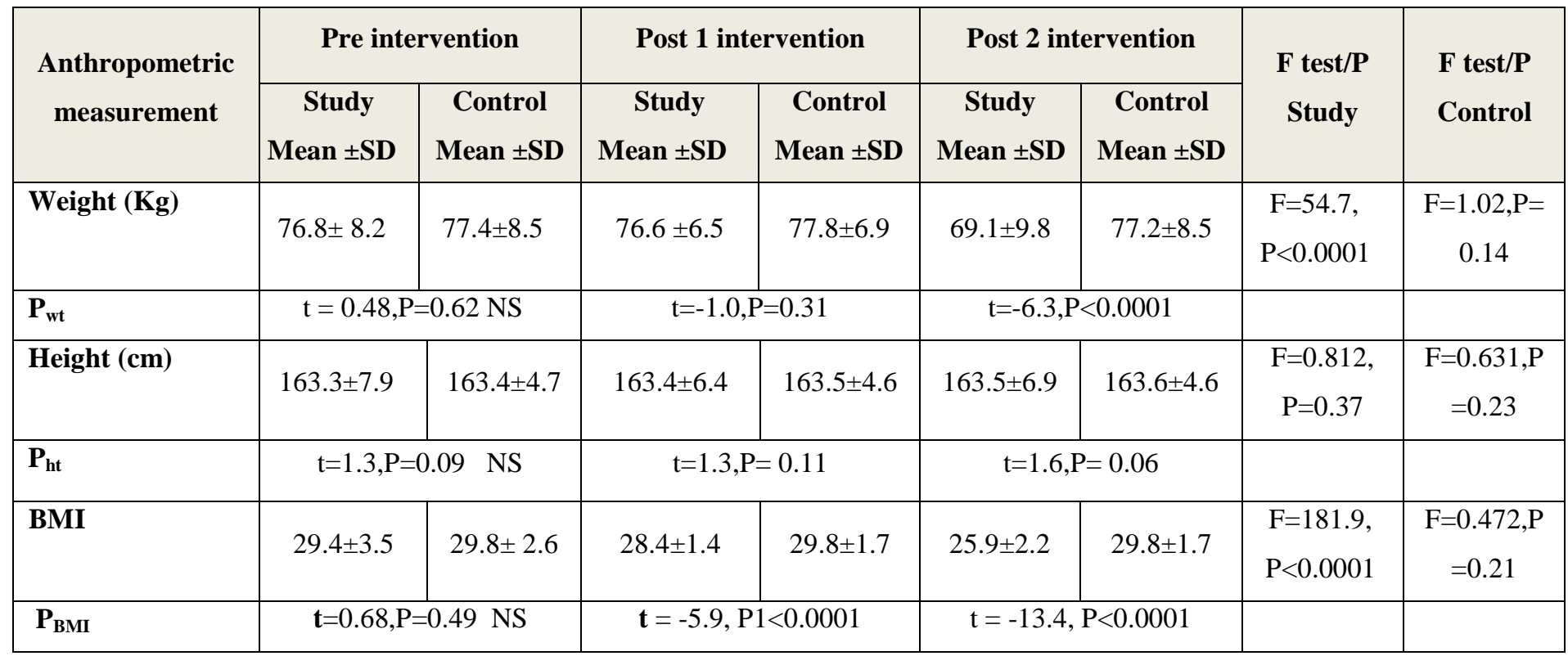




\section{University Students}

\section{Discussion}

Obesity is one of the most serious problems in the global public health domain. Obesity increases the risk of high blood pressure, dyslipidemia, type 2 diabetes, and cardiovascular diseases (WHO, 2018). Obesity is a preventable disease and the prevention of obesity is easier, less expensive, and more effective than treating obesity if it has developed (Aktar et al., 2017). Mobile health apps are widely regarded as satisfactory, simple to use, and beneficial for patients' to achieve weight loss goals. Mobile health has the ability to increase treatment adherence through strategies such as self-monitoring which has the greatest potential for facilitating weight loss (Dounavi \&Tsoumani, 2019). The purpose of the present study is to examine the effect of telephonic weight loss coaching program on body composition among health field university students.

Regarding change in dietary health habits post intervention, the current study revealed that there were positive changes in dietary health habits such as reduced number of meals taken out door, adopting healthy methods of cooking (parboiled) and vegetable oil was used in cooking rather than mixed fat in study group compared to control group. This was consistent with Adhikari \& Gollub, (2021). They studied "Evaluation of the small changes, healthy habits pilot program its influence on healthy eating and physical activity behaviors of adults in Louisiana". They reported that dietary health habits became healthier post intervention than before intervention. This was attributed to TWLC program that focused on health habits change to healthier food and physical activity behaviors and increased consumption of fruits, dark green vegetables and water.

Regarding change in health habits after attending university, the current study revealed that majority of the study sample health habits have changed to unhealthy habits such as eating unhealthy diet and not practising exercise. This was in the same line with Sogari et al., (2018). They studied" College Students and Eating Habits: A Study Using an Ecological Model for Healthy Behavior in New York, USA". They reported that when young adults leave their home circumstances, unhealthy eating habits such as lower consumption of healthy options (i.e., fruit and vegetables), irregular meals (e.g., breakfast skipping), and increased intakes of unhealthy snacks and other "junk food" increase (e.g., fried food). This was attributed to the transition phase from living at home to living alone/with roommates during the period of postsecondary education, change in 


\section{University Students}

interests, other life changes, and many food choices are deeply involved in this change. Regarding practising exercise among study university student on post intervention, the current study revealed that majority of study group practised exercise after starting TWLC program. This was congruent with Castro et al., (2020). They studied "The effects of the type of exercise and physical activity on eating behavior and body composition in overweight and obese subjects in Madrid, Spain". They found that motivation to exercise increased post intervention compared to pre intervention. This was attributed to good acceptance of the telephonic weight loss coaching program by university students.

Regarding duration and frequency of exercise, the current study revealed that duration and frequency of practising exercises has increased (30-60 min 4:6 time/week post intervention) in study group compared to control group. This was consistent with Persson \& Flodmark, (2017) they studied "Nutritional habits and physical activity among university students in Thailand". They reported that most study students practised exercise 30-60 min 3-5 times/week post intervention. This was attributed to TWLC program as it offered daily exercise videos that encouraged students to practice exercise regularly. Regarding fat percentage among study group on post intervention, the current study revealed that fat percentage was reduced among study group after intervention compared to control group. This finding was consistent with Hernández-Reyes et al., (2020), they studied" Effect of an mHealth Intervention Using a Pedometer App With Full In-Person Counseling on Body Composition of Overweight Adults in Cádiz, Andalusia, Spain". They reported that there was a significant reduction in fat percentage post intervention in study group compared to control group. This decrease in body fat was attributed to low caloric diet in combination with healthy diet and daily physical exercise offered by telephonic weight loss coaching program.

Regarding BMI among study group post intervention, the current study revealed that BMI was reduced among study group after intervention. This finding was concurrent with Durá-Travé et al., (2020) who studied "effects of the application of a prolonged combined intervention on body composition in Caucasian undergraduate students with obesity Andalucía, Spain". They found that there was a reduction in BMI after intervention. Also, this finding was in the same line with Schmittdiel et al., (2017). They studied "The Impact of Telephonic Wellness Coaching on Weight Loss among adults in Kaiser Permanente, Northern California". They reported that a significant 


\section{University Students}

change in BMI that translates to weight loss 12 months after coaching initiation in study group compared to control group. This decrease in BMI was attributed to eating low caloric diet, to practising regular exercise and changing their health habits to healthier one as a result of complying with telephonic weight loss coaching program.

There was statistically significant reduction in fat percentage and body mass index as they decreased after the program in study group compared to control group. Also there was statistically significant improvement in dietary and exercise health habits in study group compared to control group.

\section{Recommendations:}

- Mobile health nursing intervention should be followed for the management of obesity.

- Nutritional educational programs among college students should be encouraged to promote healthier eating habits and lifestyles, as well as adhering to the cultures' eating habits.

- Weight loss app should be offered in Arabic version to be suitable for persons with low or intermediate educational level.

\section{References}

Abujilban, S., Hatamleh, R., \& Al-Shuqerat, S. (2019). The impact of a planned health educational program on the compliance and knowledge of
Jordanian pregnant women with anemia. Women \& health, 59(7), 748-759.

Adhikari, P \& Gollub, E. (2021). Evaluation of the Small Changes. Healthy Habits Pilot Program: Its Influence on Healthy Eating and Physical Activity Behaviors of Adults in Louisiana. Eur. J. Investig. Health Psychol. Educ. 2021, 11, 251-262

https://doi.org/10.3390/ejihpe1 $\underline{101}$

Aktar, N., Qureshi, N. K., \& Ferdous, H. S. (2017). Obesity: a review of pathogenesis and management strategies in adult. Delta Medical College Journal, 5(1), 35-48.

Narmeen Jamal, A. A., Al-Sayyed, H. F., Zeinah, Z. A., \& Tayyem, R. F. (2021). Dietary and lifestyle habits among university students at different academic years.

Bisson, A. N. S., \& Lachman, M. E. (2017). Behavior Change with Fitness Technology in Sedentary Adults: A Review of the Evidence for Increasing Physical Activity. Front. Public Health, 4, 289.

Castro, E. A., Carraça, E. V., Cupeiro, R., López-Plaza, B., Teixeira, P. J., González-Lamuño, D., \& Peinado, A. B. (2020). The effects of the type 
Effect of Telephonic Weight Loss Coaching Program on Body Composition among Health Field

\section{University Students}

of exercise and physical activity on eating behavior and body composition in overweight and obese subjects. Nutrients, 12(2), 557.

Demirtaş, A., \& Akbayrak, N. (2017). Development of an assessment scale for treatment compliance in type 2 Diabetes Mellitus in Turkish population: Psychometric evaluation. International journal of nursing sciences, 4(3), 244-251.

Lurie, N., \& Carr, B. G. (2018). The role of telehealth in the medical response to disasters. JAMA internal medicine, 178(6), 745-746.

Diggle, P., Diggle, P. J., Heagerty, P., Liang, K. Y., \& Zeger, S. (2013). Analysis of longitudinal data. Oxford university press.

Dounavi, K., \& Tsoumani, O. (2019). Mobile health applications in weight management: a systematic literature review. American journal of preventive medicine, 56(6), 894903.

Hernández-Reyes, A., Cámara-Martos, F., Molina-Luque, R., \& MorenoRojas, R. (2020). Effect of an mHealth Intervention Using a Pedometer App With Full In-Person Counseling on Body Composition of Overweight Adults: Randomized
Controlled Weight Loss Trial. JMIR mHealth and uHealth, 8(5), e16999.

Iqbal, S. (2017). Mobile phone usage and students' perception towards Mlearning: A case of undergraduate students in Pakistan. The Journal of Distance Education/Revue de l'ducation Distance, 32(1).

Jeffrey, B., Bagala, M., Creighton, A., Leavey, T., Nicholls, S., Wood, C., ... \& Pit, S. (2019). Mobile phone applications and their use in the self-management of type 2 diabetes mellitus: a qualitative study among app users and non-app users. Diabetology \& Metabolic Syndrome, 11(1), 1-17.

Lupi, S., Bagordo, F., Stefanati, A., Grassi, T., Piccinni, L., Bergamini, M., \& Donno, A. D. (2015). Assessment of lifestyle and eating habits among undergraduate students in northern Italy. Annali dell'Istituto superiore di sanita, 51, 154-161.

Mehrzad, R. (2020). The global impact of obesity. In Obesity (pp. 55-72). Elsevier.

Moawad, M. Atia, A. Shehata, H. (2015). The effect of weight management program on body composition, fat distribution and psychosocial status among adolescent girls, not 


\section{University Students}

puplished, Menofia university, Egypt.

Nguyen, R. (2021). Identifying usability aspects with digital pupil attendance registration in a low resource context (Master's thesis).

Pal, K., Dack, C., Ross, J., Michie, S., May, C., Stevenson, F., \& Murray, E. (2018). Digital health interventions for adults with type 2 diabetes: qualitative study of patient perspectives on diabetes selfmanagement education and support. Journal of medical Internet research, 20(2), e8439.

Parkman, K. (2020). Jenny Craig vs. Nutrisystem vs. Weight Watchers Compare pricing, meal options, and weight loss results. Consumer Affairs

https://www.consumeraffairs.co

$\underline{\mathrm{m} / \text { health/jenny-craig-vs- }}$

nutrisystem-vs-weight-

watchers.html.

Persson, E., \& Flodmark, S. (2017). Nutritional habits and physical activity among university students in Thailand.

Puri-Mirza, A. (2019). Obesity prevalence adult population aged 18 years and older Egypt 2007-2016. https://www. statista. com/ statistics/ 979509
Saghafi-Asl, M., Aliasgharzadeh, S., \& Asghari-Jafarabadi, M. (2020). Factors influencing weight management behavior among college students: An application of the Health Belief Model. PloS one, 15(2), e0228058.

Schmittdiel, J. A., Adams, S. R., Goler, N., Sanna, R. S., Boccio, M., Bellamy, D. J., ... \& Ferrara, A. (2017). The impact of telephonic wellness coaching on weight loss: A "Natural Experiments for Translation in Diabetes

(NEXT-D)" study. Obesity, 25(2), 352-356.

Sogari, G., Velez-Argumedo, C., Gómez, M. I., \& Mora, C. (2018). College students and eating habits: A study using an ecological model for healthy behavior. Nutrients, 10(12), 1823

Statista, (2020). Adult obesity in the Middle East and North Africa in 2016, by country. https:// www.statista. com/ statistics /1173180/ Mena-adult-obesity-by country. Statista, (2021). Daily time spent with the internet per capita worldwide from 2011 to 2021 , by device. Retrieved from

https://www.statista.com/statisti cs/319732/daily-time-spentonline-device. 


\section{University Students}

Sullivan, A. N., \& Lachman, M. E. (2017). Behavior change with fitness technology in sedentary adults: a review of the evidence for increasing physical activity. Frontiers in public health, 4, 289.

Turner, T., Spruijt-Metz, D., Wen, C. F., \& Hingle, M. D. (2015). Prevention and treatment of pediatric obesity using mobile and wireless technologies: a systematic review. Pediatric obesity, 10(6), 403-409..

Durá-Travé, T., Gallinas-Victoriano, F., Urretavizcaya-Martinez, $\quad$ M., Ahmed-Mohamed, L., ChuecaGuindulain, M. J., \& BerradeZubiri, S. (2020). Effects of the application of a prolonged combined intervention on body composition in adolescents with obesity. Nutrition Journal, 19(1), 19.

Western Governors University (2018). How nurses help fight the obesity epidemic. Available at: https://www.wgu.edu/blog/hownurses-help-fight-obesity-

World Health Organization (WHO) (2021).Available at: https://www.euro.who.int/en/he alth-topics/diseaseprevention/nutrition/ahealthylifestyle/body-mass-index-bmi World Health Organization. (2018). Feb 16, [2019-12-17]. Obesity and Overweight.

http://www.who.int/en/newsroom/fact-sheets/detail/obesityandoverweight 